recommended. And those diagnosed with the disease after rationing began are barred from receiving Fabrazyme. The restrictions understandably make patients uneasy: many see their symptoms worsening under the new dose regime, and some have started a lawsuit against the firm. In 2010, the European Medicines Agency reported that adverse events in patients with Fabry's disease had risen since the shortage, and advised doctors to prescribe the full dose again. Genzyme's stock price dived amid screams from investors, and the company agreed early this year to be acquired by Paris-based pharmaceutical company Sanofi-aventis.

The fiasco sounded alarm bells across an industry familiar with the difficulty of manufacturing biological molecules such as antibodies and enzymes for use as drugs. These 'biologics' were once the domain of speciality biotechnology firms, but are now being produced in large quantities. The number of clinical trials involving a biologic increased from 1,197 between 2000 and 2005 to almost 6,000 in the following five years. And in 2010, the drugs brought in US $\$ 40$ billion in sales worldwide.

But success has its price. Unlike the manufacture of small-molecule drugs, which typically relies purely on large-scale chemical synthesis, biomanufacturing usually involves massive cultures of live cells maintained in rich, contamination-prone media. Anyone who has struggled to keep a 1-litre laboratory cell culture sterile will appreciate the challenge of doing the same for a 10,000-litre reactor. Viruses are stealthy intruders and can lie undetected in a culture for weeks, while the infected cells move down the pipeline to spread the scourge through the manufacturing facility - into those 10,000-litre reactors and through million-dollar chromatography columns.

This means that viral contamination can shut down drug production for months and cost a company millions of dollars, interrupting drug supplies and leaving patients vulnerable.

At least 17 incidences of viral contamination in biologics have been reported, but industry insiders say that many more go unreported. Rather than risk negative publicity and lawsuits, companies have largely chosen to keep the details of contamination, and even their occurrence, secret - even, at times, from government regulators. Genzyme's experience, which legally had to be made public because it caused a significant drug shortage, may have only deepened industry's fears of going public.

"Viruses are stealthy intruders and can lie undetected in a culture for weeks." But although secrecy may make short-term business sense, it hampers industry's collective ability to learn from these catastrophes.

Down the road from Genzyme's troubled plant, researchers at the Massachusetts Institute of Technology in Cambridge are forming a consortium with industry to tackle the problem. The academic organizers hope that it will encourage greater openness and allow industry partners to divulge confidential information under the protection of non-disclosure agreements. The consortium plans to draw lessons from contamination data that could benefit the industry as a whole, and to publish answers to questions such as where viral contaminants originate and what the best way to detect and eradicate them is, or how to prevent them altogether.

These are crucial questions as interest grows in lucrative biopharmaceuticals. The answers should be able to guide research to reduce the incidence and impact of viral contamination on drug manufacturing.

At present, only six companies have signed up to participate in the study's pilot phase, and the organizers say they will eventually need at least twenty more to draw meaningful conclusions. More biotechnology companies should embrace this rare and valuable opportunity to pool resources without compromising their business interests. It could benefit patients and investors alike.

\section{Seeing REDD}

\section{Plans to conserve the world's tropical forests must respect the rights of indigenous peoples.}

\section{A} $s$ 'REDD' projects to protect forests in developing countries gain pace, campaigners and other groups representing indigenous peoples have warned that the plans could offer little benefit to local communities that depend on the forests for their livelihoods.

REDD - reducing emissions from deforestation and forest degradation - is touted by proponents as win-win for both conservation and poverty reduction. It is based on taking money from polluters in the developed world and channelling it to tropical nations for use in protection of carbon stocks. The agreement that covers such projects, signed at the United Nations climate meeting in Cancún, Mexico, last year, includes environmental and social safeguards that call for respect for the rights of local and indigenous peoples. But forest-dependent communities and human-rights organizations fear that these provisions offer weak and ineffective protection.

These concerns are starting to play out on the ground. A study by UK-based human-rights group the Forest Peoples Programme (FPP), which looked at nine REDD pilot projects in Cameroon, warns that forest communities there have not been adequately consulted on efforts to move on from the pilot schemes to develop national REDD plans. In addition, the national plans include no measures to protect the rights of these people - such as seeking their free, prior and informed consent to projects that may affect them - nor to ensure that they benefit.

REDD was always going to have teething problems, and there will be opportunities to address these concerns. Eyes are already on an upcoming meeting of the Forest Carbon Partnership Facility (FCPF) - a global fund administered by the World Bank to help developing

nations to devise national REDD plans. At the meeting on 20-22 June in Oslo, Cameroon will present its plans, and will ask for up to US\$3.6 million to start implementing them.

Will attending conservation organizations such as the WWF, which led the development of Cameroon's REDD plans, have time to note and attempt to rectify the shortcomings identified by the FPP in time for the meeting? Perhaps not, but a subsequent meeting of scientists, international organizations and donors to discuss the social sustainability of REDD will certainly have the opportunity to examine them. The Oslo REDD Exchange will take place on 23-24 June.

An important first step would be for organizations involved in funding and driving REDD projects, such as the World Bank, to take the involvement of local communities more seriously. The FCPF has yet to finalize standards and safeguards for activities it funds, for example, those governing human rights. And it remains unclear what standards REDD projects will be measured against, given that the FCPF is just one of a number of donors. Until these issues are resolved, it will be impossible to tell whether adequate precautions are in place.

Many who follow these issues closely argue that the World Bank must lead by example, and could start by bolstering its own policies on the rights of indigenous peoples. Currently, the bank requires indigenous peoples to be 'consulted' on funded projects that may affect them. Human-rights campaigners would like to see this provision strengthened so that 'consent' is required. They are hoping that this will be a key feature of a review the bank launched last month to examine its operational safeguard policies.

The REDD initiative is too important to be undermined by a reckless disregard for indigenous peoples. It is vital that key players use this year's opportunities to steer it back on course. To ensure that

$\rightarrow$ NATURE.COM To comment online, click on Editorials at: go.nature.com/xhunqv projects on the ground run straight, funders must set a good example. Otherwise, a major opportunity to reduce carbon emissions and improve people's livelihoods will fail before it has a chance to succeed. 